\title{
An Empirical Research on the Problems and Prospects Perceived by the Small Scale Entrepreneurs in Salem District
}

\author{
S. B. Inayath Ahamed
}

\begin{abstract}
Small-scale entrepreneurs in Tamil Nadu, especially in Salem district, produce an enormous variety of products which include mass consumption goods, readymade garments, hosiery goods, electrical products, handlooms and handicrafts. The contribution of small industries in these areas to the balanced regional development of whole state as well as the country is noteworthy. This study is confined to small-scale industries which are located in Salem District of Tamil Nadu, India. Since, the objective of this study is to analyze the problem and prospects of the small-scale entrepreneurs in the study area covering a period of ten years from 2001-2002 to 2011-2012, the findings of the study will be useful for the entrepreneurs who are engaged in small-scale industries for further development and progress of their establishments and thereby growth of the economy. The research will also be useful for the academicians and policy makers.
\end{abstract}

Keywords :Small Scale Entrepreneurs, Salem District, Entrepreneurship, Problems of entrepreneur.

\section{INTRODUCTION}

In 1973, Tamil Nadu had the largest number of small-scale entrepreneurs in the country with 18,500 registered units and it has maintained this leadership, by and large. According to SIDBI (2000), in its report on small-scale entrepreneurs sector during 1988-89 to 1998-99, the Tamil Nadu SSI sector continued to grow fast. So far, there are nearly 4.20 lakhs registered SSI units and total investments nearly Rs.12, 500 cores. Small-scale entrepreneurs in Tamil Nadu, especially in Salem district, produce an enormous variety of products which include mass consumption goods, readymade garments, hosiery goods, electrical products, handlooms and handicrafts. The contribution of small industries in these areas to the balanced regional development of whole state as well as the country is noteworthy.

The opportunities in the small-scale entrepreneurs are enormous due to several factors and some of these are less capital intensive, extensive promotion and support by Government, reservation for exclusive manufacture by smallscale sector, project identification and selection, financial support \& subsidies, machinery procurement, raw material procurement, manpower training, technical \& managerial skills, tooling \& testing support. However, small-scale entrepreneurs are presently seriously

\footnotetext{
Revised Manuscript Received on December 09, 2019.

Dr.S.B.InayathAhamed, Assistant Professor, Department of Business Administration, Kalasalingum University. inayathahamed@gmail.com
}

handicapped in comparison with larger units by an inequitable allocation system for scarce raw materials and imported components, lack of provision of credit and finance, low technical skill \& managerial ability, and inadequate marketing support. To overcome all these problems, specific focus is needed in these discrepancies.

The main objective of the study is to know the problems and prospects of small-scale entrepreneurs in Salem District.

1. To study the growth and performance of small-scale entrepreneurs in Salem District.

2. To identify the problems and prospects perceived by the sample respondents in the study area.

3. To suggest suitable measures to improve the performance of small-scale entrepreneurs in Salem District.

The small-scale entrepreneurs in the study area are also facing above said problems of different magnitude. A study on the problems and prospects of small-scale entrepreneurs in the present globalized environment acquires more significance due to the existence of stiff competition both from local and external organization.

This study is confined to small-scale industries which are located in Salem District of Tamil Nadu, India. Since, the objective of this study is to analyze the problem and prospects of the small-scale entrepreneurs in the study area.

\section{METHODOLOGY}

\section{Sampling Design}

Salem district has been purposively selected for the study because large number of small-scale entrepreneurs are clustered in the area and facing heavy competition for standing in their unique business.

Hence, selecting 25 respondents from each Taluk, which constitute the size of 225 entrepreneurs, were selected randomly from nine Taluks of Salem District.

\section{DATA COLLECTION}

\section{Primary Data}

The respondents with varying backgrounds were selected based on the important aspects of their age, gender, educational status, technical qualification, generation of the entrepreneurs, Secondary Data

A number of standard text and reference books were studied to obtain pertinent literature on small-scale industries and entrepreneurs 


\section{APPROACH TO ASSESS THE EXTENT OF SATISFACTION OF ENTREPRENEURS}

The difference in the extent of satisfaction of entrepreneurs between the different types of respondents based on their age, gender, educational status, technical qualification, generation of the entrepreneurs, location of the unit, type of organization, type of ownership and years in Business taken was studied by means of Percentage, Average, Range, Standard Deviation, Two-way Tables, Chi-square test, ANOVA, Multiple Correlation Analysis, Multiple Regression Analysis, and Factor Analysis..

\section{REVIEW OF LITERATURE}

Subramanian, Shivakumar and Palanisami [1975]1 conducted a modest survey of 150 small entrepreneurs in the Madurai city and its environs, with a view to delineating the characteristics of entrepreneurs in small scale industries in a particular locality of Madurai and its environs and the influential factors of entrepreneurship.

AshisNandy and Raymond L. Owens [1977]2 analyzed on exploratory basis, some of the

1 Subramanian.R., Shiva Kumar.K., and

Palanisami.M., Entrepreneurship in Small Industries in Madurai City and its Environs, Sangam Publishers, Madras, 1975.

2 AshisNandy and Raymond L. Owens, The New Vysyas, Allied Publishers Pvt., Ltd, 1977.

Bishtand and Sharma [1991]2 have studied the entrepreneurial planning and setting by surveying 150 entrepreneurs of the Faridabad District in Harayana. Their study entails a wide spectrum of are fully planned investigative entrepreneurial dimensions involving entrepreneurial setting and some empirical evidences. The investigators found that the modern setting the caste factor is not as important as the family factor, and that the inter-generational and intra-generational influences are the dominant factors deciding the course of entrepreneurial history and its repetitive nature. An important findings of the study is that majority of the entrepreneurs surveyed have hardly any business or traditional background.

Chandra [1991]2 reported that significant differences could be found between successful and unsuccessful entrepreneurs when risk taking was considered along with other factors. The successful entrepreneurs had the risk appetite and the firm belief that innovation will rule the roost. Their quick adaptability to environmental change has kept them ahead, which the unsuccessful entrepreneurs were much hooked to their ideas and were not willing to change with the environment, 'Innovation or perish' is the new mantra for successful entrepreneurs. Entrepreneurial spirit in young minds and to advance with the help of innovation for sustain in the marketplace.

Chandra R.K, Entrepreneurial Success: A Psychological Study, New Delhi: Sterling Publishers, 1991.

\section{ENTREPRENEURSHIP}

Entrepreneurship is the dynamic process of creating incremental wealth. The wealth is created by individuals who assume the major risks in terms of equity, time or career commitment or provide value for some product or service. The product or service may or may not be new or unique, but value must somehow be infused by the entrepreneur by receiving and locating the necessary skills and resources. The entrepreneurship is usually understood with reference to individual business. Entrepreneurship has rightly been identified with the individual, as success of enterprise depends upon imagination, vision, innovativeness and risk taking. The production is possible due to the combination of the various factors of production, popularly known as land, labour, capital, market, management and of course entrepreneurship. The entrepreneurship is a risk-taking factor, which is responsible for the end result in the form of profit or loss. According to A Schumpeter "The entrepreneurship is essentially a creative activity or it is an innovative function".

\section{DATA ANALYSIS AND INTERPRETATION}

\section{A. Generation of being entrepreneur}

Number An attempt has made to know about the generation of being entrepreneur. For the purpose of this study, it has been classified into four categories viz., first generation, second generation, third generation and fourth generation. The details are furnished in the table 1.

Table 1: Generation of being entrepreneur

\begin{tabular}{|c|c|c|c|}
\hline $\begin{array}{c}\text { Generation of } \\
\text { being } \\
\text { entrepreneur }\end{array}$ & Opinion & $\begin{array}{c}\text { No. of } \\
\text { Respondents }\end{array}$ & $\begin{array}{c}\text { Prevent } \\
\text { age }\end{array}$ \\
\hline 1 & $\begin{array}{c}\text { First } \\
\text { Generation }\end{array}$ & 116 & 51.6 \\
\hline 2 & $\begin{array}{c}\text { Second } \\
\text { Generation }\end{array}$ & 65 & 28.9 \\
\hline 3 & $\begin{array}{c}\text { Third } \\
\text { Generation }\end{array}$ & 23 & 10.2 \\
\hline 4 & $\begin{array}{c}\text { Fourth } \\
\text { Generation }\end{array}$ & 21 & 9.3 \\
\hline & Total & $\mathbf{2 2 5}$ & $\mathbf{1 0 0 . 0}$ \\
\hline
\end{tabular}

It is surmised from the table 1.1 that 51.6 percent of the entrepreneurs have established their industry by their own self as first generation, 28.9 percent of the entrepreneurs are organizing and managing their industry from the parents as second generation, 10.2 percent of the entrepreneurs are organizing their industry as third generation and 9.3 percent of the entrepreneurs are organizing their industry as fourth generation. It is noted from the analysis that majority (51.6\%) of the entrepreneurs have established their industry by their own self as first generation. 


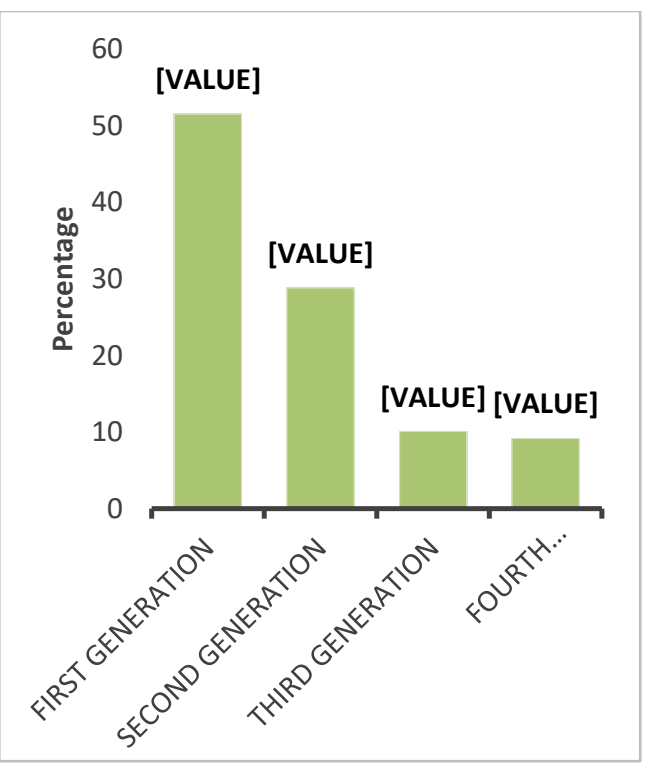

Fig 1: Generation of being entrepreneur

\section{B. Type of organization}

An attempt has made to know about the type of organization of the respondents. For the purpose of this study, it has been classified into two categories viz., production and service. The details are furnished in the table 2

Table 2: Type of organization

\begin{tabular}{|c|c|c|c|}
\hline SNo. & Type & $\begin{array}{c}\text { No. of } \\
\text { Respondents }\end{array}$ & Percentage \\
\hline 1 & Production & 192 & 85.3 \\
\hline 2 & Service & 33 & 14.7 \\
\hline & Total & $\mathbf{2 2 5}$ & $\mathbf{1 0 0 . 0}$ \\
\hline
\end{tabular}

It is identified from the table 2 that 85.3 percent of the respondents have organized the production sector and remaining 14.7 percent of the respondents have organized service sector. It is noted from the analysis that majority $(85.3 \%)$ of the respondents have organized the production sector.

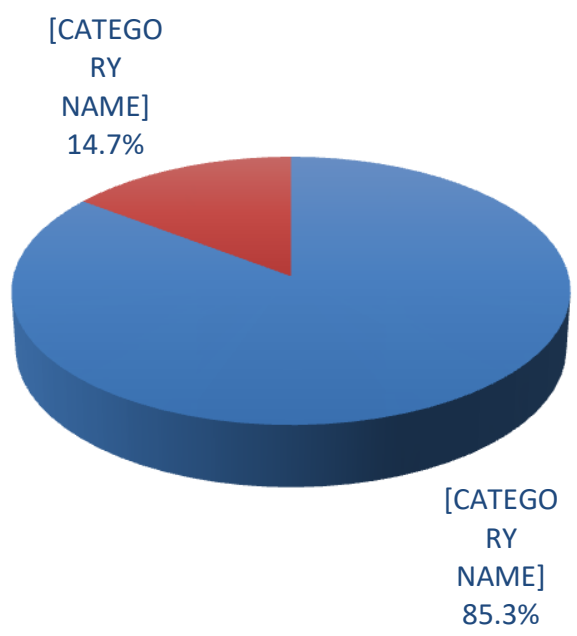

Fig 2: Type of Organization
Table 3: Level of Agreement with the organization opportunities and threats

\begin{tabular}{|c|c|c|c|c|c|c|}
\hline \multirow[b]{2}{*}{$\begin{array}{c}\text { S } \\
\text { No. }\end{array}$} & \multirow[b]{2}{*}{ Statements } & \multicolumn{5}{|c|}{ Level of Agreement } \\
\hline & & SDA & $\begin{array}{l}\text { D } \\
\text { A }\end{array}$ & $\mathbf{N}$ & $\mathbf{A}$ & $\mathbf{S A}$ \\
\hline 1. & $\begin{array}{l}\text { Globalization } \\
\text { impacts the } \\
\text { demand for } \\
\text { your products }\end{array}$ & 0 & 0 & $\begin{array}{c}2 \\
(0.9)\end{array}$ & $\begin{array}{c}135 \\
(60.0)\end{array}$ & $\begin{array}{c}88 \\
(39.1)\end{array}$ \\
\hline 2. & $\begin{array}{l}\text { The increase in } \\
\text { standard of } \\
\text { living enhances } \\
\text { your product } \\
\text { sales }\end{array}$ & 0 & 0 & $\begin{array}{c}3 \\
(1.3)\end{array}$ & $\begin{array}{c}131 \\
(58.2)\end{array}$ & $\begin{array}{c}91 \\
(40.4)\end{array}$ \\
\hline 3. & $\begin{array}{c}\text { Customer's life } \\
\text { style changes } \\
\text { influence your } \\
\text { product } \\
\text { purchase }\end{array}$ & 0 & 0 & $\begin{array}{c}4 \\
(1.8)\end{array}$ & $\begin{array}{c}103 \\
(45.8)\end{array}$ & $\begin{array}{c}118 \\
(52.4)\end{array}$ \\
\hline 4. & $\begin{array}{c}\text { Environmental } \\
\text { policies impact } \\
\text { your business }\end{array}$ & 0 & 0 & $\begin{array}{c}2 \\
(0.9)\end{array}$ & $\begin{array}{c}0.9 \\
(56.9)\end{array}$ & $\begin{array}{c}2 \\
(42.2)\end{array}$ \\
\hline 5. & $\begin{array}{l}\text { Innovation in } \\
\text { your industry is } \\
\text { very much } \\
\text { essential }\end{array}$ & 0 & 0 & $\begin{array}{c}1 \\
(0.4)\end{array}$ & $\begin{array}{c}91 \\
(40.4)\end{array}$ & $\begin{array}{c}133 \\
(59.1)\end{array}$ \\
\hline 6. & $\begin{array}{l}\text { Subsidies are } \\
\text { very much } \\
\text { essential for } \\
\text { organization }\end{array}$ & 0 & 0 & $\begin{array}{c}93 \\
(0.4)\end{array}$ & $\begin{array}{c}131 \\
(41.3)\end{array}$ & $\begin{array}{c}225 \\
(58.52 \\
\quad)\end{array}$ \\
\hline
\end{tabular}

(SDA-Strongly Disagree, DA-Disagree, N-Normal, A-Agree, SA-Strongly Agree)

It is substantiated from the table 3 that the respondents are agreed towards the statements like globalization impacts the demand for their products, the increase in standard of living enhances your product sales and environmental policies impact your business as 60.0, 58.2 and 56.9 percent respectively. On the other hand, the respondents are strongly agreed towards the statements like customer's life style changes influence their product purchase, innovation in their industry is very much essential and subsidies are very much essential for organization as 52.4, 59.1 and 58.2 percent respectively. It is concluded from the analysis that majority $(60.0 \%)$ of the respondents are agreed towards globalization impacts the demand for their products as the organization opportunities and threats.

\section{Mode of sales and level of satisfaction}

Marketing channel helps to clear the produced stocks by various modes of sale. For the purpose of this study, mode of sales has been classified into three categories viz., direct selling, through wholesaler and through retailer. The sample consists $119(52.9 \%)$ of the respondents are selling the product in the direct way, $70(31.1 \%)$ of the respondents are selling the product through wholesaler and $36(16.0 \%)$ of the respondents are selling the product through retailer.

The distribution of sample respondents according to mode of sales and level of satisfaction towards small scale industries are shown in the table 4 
Table 4: Mode of sales and level of satisfaction

\begin{tabular}{|c|c|c|c|c|c|c|c|}
\hline \multirow[b]{2}{*}{$\begin{array}{c}\text { S } \\
\text { No }\end{array}$} & \multirow[b]{2}{*}{$\begin{array}{c}\text { Mode } \\
\text { of Sales }\end{array}$} & \multirow{2}{*}{$\begin{array}{c}\text { No. of } \\
\text { Resp } \\
\text { onde } \\
\text { nts }\end{array}$} & \multirow[b]{2}{*}{$\%$} & \multirow[b]{2}{*}{$\begin{array}{c}\text { Aver } \\
\text { age }\end{array}$} & \multicolumn{2}{|c|}{ Range } & \multirow[b]{2}{*}{ S.D } \\
\hline & & & & & $\begin{array}{l}\text { M } \\
\text { in }\end{array}$ & $\begin{array}{l}\mathrm{M} \\
\mathrm{ax}\end{array}$ & \\
\hline 1 & $\begin{array}{l}\text { Direct } \\
\text { selling }\end{array}$ & 119 & 52.9 & 49.3 & 29 & 55 & 3.2 \\
\hline 2 & $\begin{array}{c}\text { Throug } \\
\text { h } \\
\text { wholesa } \\
\text { ler }\end{array}$ & 70 & 31.1 & 49.6 & 42 & 59 & 3.5 \\
\hline 3 & 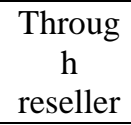 & 36 & 16.0 & 50.3 & 46 & 56 & 2.9 \\
\hline & Total & 225 & 100.0 & & & & \\
\hline
\end{tabular}

It could be surmised from the table 4.80 that the level of satisfaction of the small scale entrepreneurs selling their products in a direct way ranged between 29 and 55 with an average of 49.3. The level of satisfaction of the small scale entrepreneurs selling their products through wholesaler ranged between 42 and 59 with an average of 49.6. On the other hand, the level of satisfaction of the small scale entrepreneurs selling their products through retailer ranged between 46 and 56 with an average of 50.3. From the analysis, it is noted that the maximum level of satisfaction towards small scale entrepreneurs who selling their products through retailer.

With a view to find the degree of association between mode of sales and level of satisfaction towards small scale industries, a two-way table was prepared and it is shown in the table 4 .

\section{Finding}

1) It is noted that majority $(51.6 \%)$ of the entrepreneurs have established their industry by their own self as first generation.

2) It is noted that majority (85.3\%) of the respondents have organized in to the production sector

3) It is inferred that the maximum level of satisfaction towards the small scale industries perceived by the respondents in the age group of below 30 years. It is accepted by the Chi-squared test at 5 percent level of significance association.

4) It is noted that the maximum level of satisfaction towards small scale entrepreneurs who selling their products through retailer. It is accepted by the Chisquared test at 5 percent level of significance association.

\section{E. Suggestion}

The study also finds that majority of the entrepreneurs are hesitant to start an enterprise mainly due to lack of self-confidence and adequate knowledge about the various intricacies of the business. Hence it is suggested that to overcome this problem, Government and other agencies can take up the task of imparting personality development courses to boost up the self confidence among the entrepreneurs.

\section{CONCLUSION AND FUTURE}

In this study the researcher has attempted to provide an insight into the life of small scale entrepreneurs in Salem district. Better style of administration is required which can be gained through learning the professional course like management and information technology. This will help the entrepreneurs to be more successful in their business and also help the entrepreneurs to face the competition in the international level very easily.

The study was limited to the respondents of Salem city and further studies can consider developing a systematic study to include or compare various parts of the district and other industrial regions.

\section{REFERENCES}

1. Subramanian.R., Shiva Kumar.K., And Palanisami.M. Entrepreneurship In Small Industries In Madurai City And Its Environs, Sangam Publishers, Madras, 1975

2. AshisNandyAnd Raymond L. Owens, The New Vysyas, Allied Publishers Pvt., Ltd, 1977.

3. Chandra R.K, Entrepreneurial Success: A Psychological Study, New Delhi: Sterling Publishers, 1991. Delhi, 1989.

4. Patel V.G, "Entrepreneurship Development Programs in India" in 'Development of New Entrepreneurs', EDII, Ahmedabad,1987, p.1-40.

5. NarasimhaMurthy.B.E.V.Y.,Entrepreneurship in Small Towns, Mittal Publications, New Delhi, 1989.

\section{AUTHORS PROFILE}

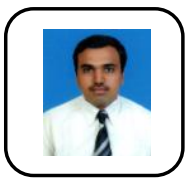

Dr.S.B.Inayath Ahamed is working as Assistant Professor in the Kalasalingam Business School. He had Cleared UGC NET,SET in the year 2012. He had published many quality research papers in the journals of repute. 